\title{
Research on the Innovative Packaging Design of the Tourist Souvenirs in Regional Intangible Cultural Heritages
}

\author{
Yan Dong ${ }^{1, ~ a ~}$ \\ ${ }^{1}$ Dalian University Of Science And Technology
}

No.999-26, bingang road, Ivshun economic development zone, dalian, liaoning province, China

a274261074@qq.com

Keywords: Intangible cultural heritages; tourist souvenirs; packaging design; innovation

Abstract: The package of the tourist souvenirs in the intangible cultural heritages is one of the topics that people pay less attention to, but with the rapid development of tourist industry as well as the transformation of intangible cultural heritages, it has caught their eyes gradually. The paper is meant to explore a way for the packaging design of the tourist souvenirs with innovation through the analysis of the propagation characteristics of the tourist souvenirs in intangible cultural heritages and the combination of the packaging design elements and the innovative design of tourist souvenirs.

\section{The Current Situation of the Tourist Souvenirs in Intangible Cultural Heritages}

In the first half year of 2017, China has received about 1.352 billion tourists all over the world with a year-on-year growth of $14.7 \%$, and also achieved its tourist income of 938.3 billion yuan with a increase of $24.2 \%$, which indicating that our country's tourist industry has stepped into a "golden age". It is reported that at present 27 provinces and municipalities has already positioned the tourist industry as the pillar industry or the leading industry of the tertiary industry and that the provinces and municipalities like Beijing, Shanghai, Jiangsu, Yunnan, Guizhou, and Xinjiang have clearly proposed to make the tourist industry into their strategic pillar industry [1]. As we all know, the rapid growth of tourist industry is able to facilitate the fast and sustainable development of industries related to commerce, food, hotel, civil aviation, railway, highway, garden, daily light industry, arts and crafts, as well as post and telecommunications. As an important part of tourist industry, the tourist souvenirs have played a more and more prominent role in giving better emotional experience and tourism impression to visitors.

The tourist souvenirs can be generally sorted out into three kinds, including the articles used for tourist management such as the tickets for tourist attractions and transportation means, tourist commodities such as featured handicrafts, calligraphy, clothes, and local speciality, and tourism service products such as tourist map, instruction, book and video [2]. Along with people's rising awareness of protecting the intangible cultural heritages, its tourist souvenirs have been gradually highlighted.Those souvenirs all imply special natural, historical, regional, and cultural properties, thus being the carrier for the transmission of China's thousand years of civilization; the innovation design and development of those souvenirs are also an effective means to publicize and protect the intangible cultural heritages.

Currently, as government attaches more importance to the development of cultural tourist souvenirs and all levels of expos and tourist souvenirs design contests are held frequently, the development of tourist souvenirs has received more attention at present. However, under the prosperous and flourishing background, there are severe homogenization in the design and development of tourist souvenirs in our country. Lack of innovation, repeated imitation, and cultural connotation shortage are problem commonly existing; besides, the rough production, lack of innovative design, unclear position of target consumers, conservative packaging and sales means, and poor quality have greatly affected the rapid development of tourist industry. 


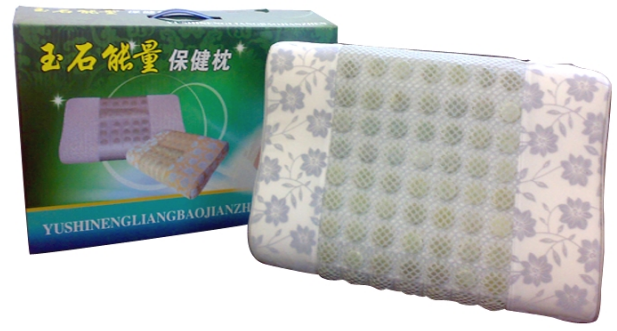

Fig. 1 Package of Xiuyan jade pillar made by Zhonghe Xiuyan Jade Factory, Xiuyan county, Liaoning Province

\section{Analysis of the Packaging Design Elements Based on Intangible Cultural Heritage Resources}

So far, our country has had developed 28 international intangible cultural heritages, and 117,5 national intangible cultural heritages, and every province and municipality has established its own intangible cultural heritage protection system [3]. There are various kinds of intangible cultural heritages, including images, skills, sounds, and others; those available for the packaging design of tourist souvenirs are listed in the following Table 1.

Table 1 Analysis of the Elements in the Intangible Cultural Heritage Resources Available for Packaging Design of the Tourist Souvenirs

\begin{tabular}{|c|c|c|c|c|c|c|}
\hline Image & Colour & Styling & $\begin{array}{l}\text { Character } \\
\text { and Sign }\end{array}$ & Material & $\begin{array}{c}\text { Cultural } \\
\text { Connotation }\end{array}$ & Performance \\
\hline $\begin{array}{l}\text { Traditional dance } \\
\text { and traditional art }\end{array}$ & $\begin{array}{l}\text { Traditional } \\
\text { art, dance, } \\
\text { festival, } \\
\text { etiquette, } \\
\text { Chinese } \\
\text { music }\end{array}$ & $\begin{array}{l}\text { Traditional } \\
\text { folk } \\
\text { customs } \\
\text { such as art, } \\
\text { etiquette, } \\
\text { festival }\end{array}$ & $\begin{array}{l}\text { Traditional } \\
\text { art and folk } \\
\text { customs } \\
\text { such as } \\
\text { Chinese } \\
\text { calligraphy } \\
\text { and festival }\end{array}$ & $\begin{array}{l}\text { Knowledge } \\
\text { and } \\
\text { practice } \\
\text { related to } \\
\text { nature and } \\
\text { universe, } \\
\text { and other } \\
\text { intangible } \\
\text { cultural } \\
\text { heritages }\end{array}$ & $\begin{array}{l}\text { Traditional } \\
\text { folk customs } \\
\text { such as } \\
\text { etiquette and } \\
\text { festival }\end{array}$ & $\begin{array}{l}\text { Traditional } \\
\text { oral literature, } \\
\text { language, } \\
\text { music, folk art, } \\
\text { dance, drama, } \\
\text { acrobatics, and } \\
\text { sports }\end{array}$ \\
\hline
\end{tabular}

\section{Extracting the Images of the Intangible Cultural Heritages}

The traditional dance such as yangko (a popular rural folk dance in China) and the traditional arts such as dough figurine, cloth tiger, and sugar figurine are available for people to extract the useful images, clothes, and appearances. It is able to develop the plane or solid packaging images through the division and further processing of the intangible cultural heritages as well as the combination with the shape of the tourist souvenirs itself.

\section{Extracting Distinct National Colors}

In terms of different kinds of intangible cultural heritages, we can make categories from different regional features and nationalities; we develop and extract packaging elements, according to the colour preferences and taboos of different nationalities. For example, the Yi nationality worships black, red, and yellow colors [4], so the special tourist souvenir package is able to be designed with different national colors.

Designing the Package with a Styling Suitable for the Intangible Cultural Heritage Tourist Souvenirs

The package and styling of intangible cultural heritage resources should not only reflect their cultural and historical properties, but also coordinate the package and their nature as tourist souvenirs. A number of elements in the intangible cultural heritages can be used for the styling of tourist souvenir package, such as the stone carving, jade carving, wood carving, peath-stone carving, coconut carving, bottle gourd carving, and tin carving in the traditional arts, the special clothes of the She nationality, the Li nationality, the Tibetan nationality, the Yugu nationality, and the Lhoba nationality. In addition, the 
package can be also designed by making the distinct images more abstract.

The Innovative Development of National Character and Totem Image

As the traditional Chinese characters, signs, and totems serves as the witness of Chinese history, the characters and signs themselves can be also taken as the elements for the packaging design of tourist souvenirs. The image of the character itself is available for the appearance of the package with its unique national colors and profound regional and cultural properties, such as Dongba paintings by the Naxi nationality in the Chinese folk arts and Shui scripts and Nushu (female scripts) in the folk customs.

\section{Strategies of Positioning an Innovative Tourist Souvenir Package in Intangible Cultural Heritages}

\section{Regional culture in the Innovative Intangible Cultural Heritage Souvenir Package}

The intangible cultural heritages in different regions has distinctive features, so the innovation of the package can be achieved in terms of the regional differences. For example, as south China, northeast China, Sichuan area, and Hubei area have formed its unique cultures and aesthetic tendency under different geographical and national environment, we can make use of regional features when developing special tourist souvenirs, which despite the same kind of products, will embody different aesthetic pursuits because of their different aesthetic tastes and ideas. Therefore, to seek for difference is an important way to shape distinctive tourist souvenirs. What's more, those regional images, colors, and characters in package of the tourist souvenirs are able to show the unique features of intangible cultural heritages.

\section{Human Design and Innovation in the Innovative Intangible Cultural Heritage Souvenir Package}

The package of tourist souvenirs in intangible cultural heritages should not only consider its commercial property, but also integrate it with human design to stress the humane spirits and the harmony between human and product [5]. When achieving its own function, the package of the product should adopt a more friendly design and lay emphasis on the quality of product package as well as its research on Kansei Engineering, so as to reflect its difference. For instance, special tourist souvenirs have been designed through the local firing skills in the Uyghur Nationality, Jingdezhen, Yaozhou, Longquan, and Cizhou [6] and the combination of the shapes of ceramics; they are easy to carry and move with the proper package to match the shape of ceramics, thus preventing the commodity from being crushed.

\section{Tourists-based Package and Innovation of Intangible Cultural Heritage Souvenirs}

According to the collection values, the tourist souvenirs can be classified into the high-end collection and the mid-low end consumable. Beside the classification, the souvenirs are also able to be categorized in terms of the target market and consumers. At present, tourists can be divided into several groups by age: children, the youth dominated by lovers and students, mid-aged businessmen, and the old. The package of the products developed for the children should be partial to their aesthetic psychology in the treatment of images, colors, and characters; in order to guarantee children's safety, we should think about the integral package and its soft quality. The package of the products for the young people like lovers and students should highlight the emotional reveal by adding emotion property. The package of the products for the mid-aged businessmen must pay attention to the quality promotion and satisfy their pursuit of high taste. At last, the package of the products for the aged tourists should be more human and considerate with added practical values.

\section{Strategies of Positioning the Styling of Tourist Souvenir Package in Intangible Cultural Heritages}

\section{Positioning the Package Styling of the Articles Used for Tourist Management}

The packaging design of the articles used for tourist management needs more deliberations of the materials and external forms. The use of special papers or handicrafts in the region as well as the thorough shape of external form is able to promote the image of the intangible cultural heritage 
souvenirs. For example, the odd treatment of the ticket shape, the die-cutting of the ticket surface, the coining processing, or the laser printing are all available to enrich the profound meanings and endow with distinct features.

\section{Positioning the Package Styling of Tourist Commodities}

\section{Utensil}

The package of utensil needs to take the proper exhibition of the product itself into account, and meanwhile it must think over the adoption of the minimized, simplified, and purified green materials. It is meant to realize the ecological package [7] by making the best of green materials such as fibre braided fabric, wicker, reed, crop straw, and ear of wheat. For instance, packaging porcelain products with bamboo materials has an air of traditional Confucian culture.

\section{Calligraphy and Painting}

The traditional package of calligraphy and painting is mainly made of paper materials, but due to the particular characteristics of papers, the package has also had some problems, such as easy to be affected by nature, environment, and human forces. Therefore, the package of calligraphy and painting should take sufficient consideration of those factors and their moister-proof, quake-proof, and lasting properties. The souvenir of Thousand-charcter Calligraphy by Zhu Xi designed by Lu Jingren has not only paid attention to the inheritance of traditional Chinese culture, but also had an ideal protection of the product itself with a book coat.

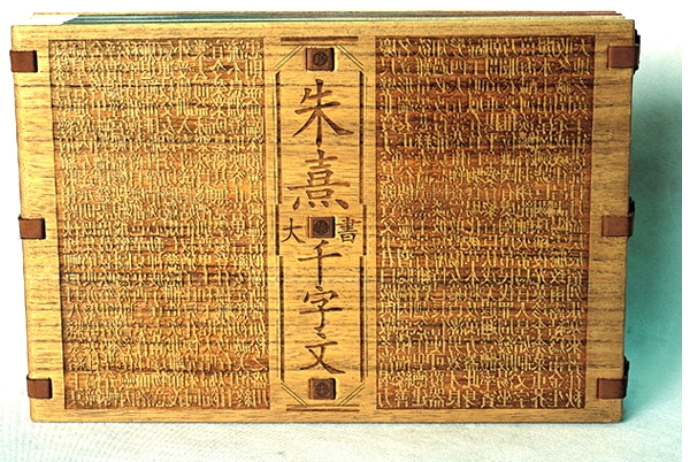

Fig. 2 Thousand-charatcer Classic by Zhu Xi designed by Mr. Lv Jingren from www. Meishujia.cn

\section{Local Specialty}

The package of the local specialty should consider both its utility and regional features of the intangible cultural heritages, in order to disclose its regional and cultural properties as well as the unique brand and thus improve the brand add-values. For example, in the development of mountain products, we should promote its quality and develop a series of brand products, and produce simple set, mixed group set, and the high-end gift set and luxury set, so as to form a distinctive package based on regional colors, whether in the styling or in the visual taste.

\section{Toy}

The packaging design of toy souvenirs needs more considerations of the acceptance of consumers. The target consumers of toys are children, so its package should be secure, simple, visual, and human, and when having realized the aesthetic function and cultural function, it should emphasize more on its interestingness, utility, and harmlessness. Besides, the design of the package can also be integrated with the local historical legends, folk stories, folk puppets, and folk customs, so as to develop a kind of package with certain cultural connotation.

\section{Positioning the Package Styling of Tourist Service Products}

\section{Audio and Video Products}

The audio and video products in the intangible cultural heritages should firstly reveal the implied historical and cultural connotations in the package. The traditional opera, performance, festival, etiquette, and quyi are all possible to be developed into audio and video tourist souvenirs, thus inheriting the intangible cultural heritages with preservable and transmittable forms; meanwhile, we can enrich the traditional package forms of audio and video products, relying on hi-tech and integrating 
with fashionable and dynamic elements, such as adding flash animation in the audio and video products and combining the internet and new media mobile terminal to realize the interactive transmission and remote request.

\section{Tourist Map and Instruction}

For the human development of tourist map and instruction book, media can be integrated to realize convenience, while regional features are also reflected. For one thing, the high technology should be employed such as the voice guide, GPS positioning guide, animation tourist map; for another, the traditional handicrafts are able to be combined, such as the local hand-made paper printing and the regional woodblock printing, so as to enrich the package forms of tourist souvenirs.

\section{Conclusions}

The development of intangible cultural heritage tourist souvenirs should take the packaging design elements into consideration, and also combine with different types of the intangible cultural heritage resources. For the innovation of the package design, designers should consider the geo-culture of the intangible cultural heritage itself, accurately position the target customers of the tourist souvenirs, and properly emphasize the properties of different packages, thus integrating them with different design and innovation ideas. For the styling design of the package, designers should employ various craft techniques of the intangible cultural heritages, and ensure the package of intangible cultural heritage souvenirs with an environmental-friendly concept of green ecology and the appropriate packaging function, so as to transmit the intangible cultural heritage resources.

\section{References}

[1] http://www.chinanews.com/life/2011/09-26/3353948.shtml (2011.09.26)

[2] Gao Aimin, Zhang Ruchuang and Ye Liwen: An Introduction to the Management of Tourism Products, China Social Sciences Press (1991)

[3] www.chinaich.com.cn (2011.10.8)

[4] Yang Liu and Liu Yu: research on the Color Worship and Decoration Art of the Yi Nationality, Shangqing (2011)

[5] Wang Wuyun: Research on the Human Design of the Industrial Products, Journal of Inner Mongolia University (2006)

[6] http://www.cctv.com/history/special/C15515/20060417/101868.shtml

[7] Su Yi and Zeng Zhaowang: Green Package of Daily Porcelain, Chinese Ceramics (2008) 